\title{
Young Cassavapreneurs Indonesia: Strategi Pembelajaran Kewirausahaan “Lawang Lima Sampeureun Jaga” di Desa Benteng
}

\section{(Young Cassavapreneurs Indonesia: Entrepreneurship Learning Strategies "Lawang Lima Sampeureun Jaga" in Benteng Village)}

\author{
Sultan Laga Putra Azdi ${ }^{1}$, Maulida Nurul Fatkhiyatut Taufiqoh ${ }^{1}$, Zakiyah Salsabila Syafhil ${ }^{1}$, Flamora \\ Gresafira Cahya ${ }^{2}$, Sri Wiji Utami ${ }^{3}$, Lindawati Kartika ${ }^{{ }^{*}}$ \\ ${ }^{1}$ Departemen Manajemen, Fakultas Ekonomi dan Manajemen, Institut Pertanian Bogor, \\ Kampus IPB Darmaga, Bogor 16680. \\ 2 Departemen Sains Komunikasi dan Pengembangan Masyarakat, Fakultas Ekologi Manusia, Institut Pertanian Bogor, \\ Kampus IPB Darmaga, Bogor 16680. \\ 3 Departemen Gizi Masyarakat, Fakultas Ekologi Manusia, Institut Pertanian Bogor, Kampus IPB Darmaga, Bogor 16680. \\ *Penulis Korespondensi: lindawati.kartika@gmail.com \\ Diterima Juli 2019/Disetujui Desember 2019
}

\begin{abstract}
ABSTRAK
Young Cassavapreneurs Indonesia (YCPI) merupakan program yang ditujukan untuk menjawab permasalahan seperti pemanfaatan ubi kayu yang belum optimal, pentingnya untuk menanamkan jiwa wirausaha kreatif pada remaja desa, dan rendahnya partisipasi pendidikan penduduk Desa Benteng. Desa Benteng terletak di Kecamatan Ciampea, Kabupaten Bogor. Tujuan dari program ini adalah 1) Meningkatkan pengetahuan, keterampilan dan sikap wirausaha siswa kejar paket dan sekolah terbuka di Desa Benteng; 2) Meningkatkan nilai ekonomi ubi kayu yang merupakan potensi Desa Benteng; dan 3) Membentuk struktur kelembagaan wirausaha baru berbasis kearifan lokal. Metode yang digunakan adalah The House Model Horovitz dan Ohlsson-Corboz serta metode Balanced Scorecard. Data primer diperoleh dengan wawancara dan kuesioner. Konsep The House Model dibagi menjadi tiga bagian, yakni goal dan partnership (atap), Lawang Lima Sampeureun Jaga (tengah), dan proses kegiatan belajar mengajar (fondasi). Secara keseluruhan program YCPI yang terdiri atas 9 sasaran kinerja dan 15 indikator utama telah mencapai target $100 \%$. Keberhasilan tersebut juga didukung dengan pre-test dan post-test, dan evaluasi peningkatan pengetahuan, keterampilan, dan sikap. Hasil pre-test dan post-test menunjukkan persentase hasil capaian pembelajaran para peserta $\geq 3$ adalah $100 \%$ atau terjadi peningkatan pengetahuan, keterampilan, dan sikap para siswa secara keseluruhan setelah program berakhir.
\end{abstract}

Kata kunci: Desa Benteng, kewirausahaan, lawang lima sampereun jaga, YCPI

\begin{abstract}
Young Cassavapreneurs Indonesia (YCPI) is a program that aims to address problems such as the utilization of cassava that is not yet optimal, the importance of instilling the spirit of creative entrepreneurship in youth, and low education of Benteng villagers. Benteng Village locates in Ciampea, Bogor District. The objectives of this program are 1) Increase the entrepreneurial knowledge, skills, and attitudes of students pursuing high school equivalency and open-school in Benteng Village; 2) Improve the economic value of cassava which is the potential commodity of Benteng Village, and 3) Establish a new small enterprise based on local wisdom. Primary sources of data are from interviews and questionnaires. The methods used are the House Model Horovitz and OhlssonCorboz and the Balanced Scorecard method. The House Model concept divided into three parts: specific goal and partnership (roof), Lawang Lima Sampeureun Jaga (middle), and the process of teaching and learning activities (foundation). Overall, the YCPI Program, which consists of 9 performance targets and 15 key indicators, has reached the target of $100 \%$. Pretest, posttests, and also the evaluation of increasing knowledge, skills, and attitude of students are the factors of the successful YCPI program. The pre-test and post-test results showed the percentage of the learning outcomes of the participants $\geq 3$ was $100 \%$ or there was an increase in the knowledge, skills, and attitudes of the students as a whole after the program ended.
\end{abstract}

Keywords: Benteng Village, entrepreneurship, lawang lima sampereun jaga, YCPI 


\section{PENDAHULUAN}

Pendidikan merupakan hak segala bangsa, hal ini secara jelas tercantum dalam Undang-Undang Dasar 1945 Pasal 31. Pada ayat pertama tertulis bahwa setiap warga negara berhak mendapat pendidikan. Fakta menunjukkan pada tahun 2018 angka putus sekolah di Indonesia masih tinggi mencapai 114.440 siswa. Menurut data BPS (2018) Jawa Barat menduduki urutan pertama provinsi dengan angka putus sekolah tertinggi, yakni sejumlah 17.715 siswa. Untuk mengatasi masalah tersebut sekolah terbuka dan kejar paket dihadirkan pemerintah sebagai solusi. Sekolah terbuka dan kejar paket telah diselenggarakan di berbagai daerah di Indonesia termasuk di Provinsi Jawa Barat.

Desa Benteng merupakan sebuah desa yang terletak di Kecamatan Ciampea, Kabupaten Bogor. Pendidikan masih didominasi oleh lulusan sekolah dasar dan sekolah menengah pertama, yakni sebesar $55 \%$. Di desa tersebut terdapat SMP Terbuka serta Program Kejar Paket B dan C yang dikelola oleh komunitas pendidikan yang bernama Komunitas Pendidik Nusa. Selama ini siswa SMP Terbuka dan kejar paket hanya mendapatkan mata pelajaran untuk memeroleh Surat Tanda Tamat Belajar (STTB). Berbeda dengan sekolah reguler pada umumnya yang menyediakan wadah bagi para siswa melalui ekstrakurikuler untuk mengembangkan keterampilan penunjang. Berdasarkan hasil diskusi dengan Komunitas Pendidik Nusa, ternyata para siswa memerlukan bekal tambahan berupa keterampilan berwirausaha untuk menjadi generasi muda yang memiliki daya saing. Hal ini sejalan dengan salah satu sasaran strategis Kementerian Pemuda dan Olahraga (2018), yaitu kewirausahaan merupakan komponen yang sangat penting untuk mewujudkan generasi muda yang berdaya saing.

Desa Benteng memiliki potensi sumber daya alam berupa komoditas ubi kayu dengan harga Rp2.700. Selain itu masyarakat Desa Benteng hanya mengolah ubi kayu menjadi combro, misro, ubi kayu rebus, serta olahan sederhana lainnya. Oleh karena itu, diperlukan upaya pemanfaatan ubi kayu melalui pengolahan menjadi aneka produk yang bernilai ekonomi lebih tinggi dan lebih tahan lama. Berdasarkan masalah yang dihadapi komunitas pendidik nusa, yakni perlunya peningkatan pengetahuan dan keterampilan tentang kewirausahaan serta adanya potensi ubi kayu di Desa Benteng yang belum termanfaatkan secara optimal maka pelaksana kegiatan sebagai mahasiswa mengusulkan program Young Cassavapreneurs Indonesia (YCPI). Program YCPI memberikan pelatihan kewirausahaan mulai dari pengadaan bahan baku, pengolahan bahan baku menjadi produk nilai jual tinggi, perhitungan harga jual, hingga pemasaran produk. Target program YCPI ialah remaja Desa Benteng, khususnya siswa kejar paket yang memiliki permasalahan ekonomi. Program YCPI bertujuan untuk meningkatkan pengetahuan, keterampilan, dan sikap wirausaha siswa kejar paket dan sekolah terbuka di Desa Benteng, meningkatkan nilai ekonomi ubi kayu yang merupakan potensi Desa Benteng, dan membentuk struktur kelembagaan wirausaha baru berbasis kearifan lokal. Program YCPI diharapkan dapat membentuk wirausaha muda untuk memajukan perekonomian Desa Benteng.

\section{METODE PELAKSANAAN PROGRAM}

Program YCPI dilaksanakan pada bulan Maret-Juli 2019. Program YCPI telah melaksanakan 10 pertemuan dengan durasi waktu rata-rata 3 jam per pertemuan. Program dilaksanakan di Desa Benteng tepatnya di rumah Ketua Komunitas Pendidik Nusa dan Ketua KWT Barokah. Komunitas Pendidik Nusa merupakan komunitas yang bergerak di bidang pendidikan dan sosial di Kabupaten Bogor. Sumber data primer dari wawancara sedangkan data sekunder diperoleh dari laporan tahunan Desa Benteng, laporan kinerja Kemenpora 2018, dan jurnal terkait. Pengolahan data pre-test dan posttest dilakukan dengan menghitung rata-rata aspek pengetahuan, keterampilan, dan sikap. Hasil rata-rata tersebut disajikan dalam bentuk grafik dengan membandingkan perbedaan nilai pre-test dan post-test pada ketiga aspek. Metode yang digunakan untuk analisis program YCPI adalah metode The House Model (Horovitz \& Ohlsson 2007) dan perhitungan Balanced Score Card (Kaplan \& Norton 2000). Perhitungan Balance Score Card dilakukan melalui beberapa langkah, yaitu 1) Cascading visi, misi, dan sasaran pada unit kerja terkait; 2) Membuat kartu skor yang sesuai dengan kaidah SMART; 3) menentukan indikator kinerja utama (IKU); 4) Perhitungan range skala sangat baik, baik, cukup, dan rentah untuk setiap IKU; 5) Perhitungan bobot tiap IKU; dan 6) Perhitungan capaian yang telah direalisasikan.

Program YCPI dilaksanakan dengan metode Lawang Lima Sampereun Jaga untuk menjawab 
persoalan tersebut. Metode Lawang Lima Sampereun Jaga merupakan adaptasi dari Lawang Salapan Sampeureun Jaga sebagai ciri khas Bogor, Lawang yang artinya pintu dan Salapan yang artinya sembilan. Lawang Lima Sampeureun Jaga memiliki makna lima pintu kewirausahaan sebagai bekal untuk kesuksesan di masa depan. Empat Lawang dari Lawang Lima tersebut adalah pengadaan bahan baku, pengolahan produk, pengemasan, dan analisis harga jual serta pemasaran dan promosi bersumber pada Lembaga Sertifikasi Profesi (LSP) Menbiska, sedangkan penanaman motivasi bersumber pada Purwanto (2000). LSP Menbiska merupakan pelaksana uji kompetensi kewirausahaan, program YCPI mengadopsi kurikulum kewirausahaan industri tersebut. Setiap lawang memiliki tiga tahapan kegiatan, yaitu persiapan, implementasi, serta monitoring dan evaluasi.

Berdasarkan Gambar 1 dapat diketahui bahwa implementasi program YCPI terdiri atas tiga bagian, yakni atap yang merupakan tujuan utama, bagian lawang (tengah), dan bagian dasar yang merupakan proses kegiatan belajar mengajar YCPI. Pada kegiatan kerja sama pada bagian atap didukung oleh konsep Pentahelix (Amrial et al. 2017) melalui kerja sama yang dijalin untuk mencapai tujuan akhir program, yaitu makmur bersama YCPI di Desa Benteng. Konsep Pentahelix tersebut tediri dari berbagai kalangan seperti akademisi, pemerintah, dan non pemerintah (NGO), masyarakat dan komunitas. Pada bagian atap, lawang maupun dasar disusun masingmasing indikator kinerja utama dan sasaran kinerja, keseluruhan bagian dari model tersebut menuju tujuan akhir dari program, yakni makmur bersama cassavapreneur di Desa Benteng, Kabupaten Bogor. Tahapan program Young Cassavapreneurs Indoesia mulai dari tahap identifikasi masalah hingga tercapainya tujuan program dapat dilihat pada Gambar 2.

\section{HASIL DAN PEMBAHASAN}

Evaluasi program YCPI dinilai menggunakan Balance Score Card yang mengacu pada metode 'Lima Lawang Sampereun Jaga', yakni lawang penanaman motivasi (PM), pengadaan bahan baku (PB), pengolahan (PO), pengemasan dan analisis harga (PH), serta pemasaran (PP). Tiap lawang terdiri dari sasaran kinerja dan masingmasing sasaran kinerja berisi indikator kinerja utama (IKU). Memaknai The house model yang mana merupakan bentuk sederhana dari kegiatan YCPI, maka lima lawang sebagai metode pembelajaran YCPI memiliki pondasi landasan, yakni kegiatan belajar mengajar (KBM) dan kegiatan partnership yang merupakan komponen landasan atap dari tujuan utama program, yakni makmur bersama cassavapreneurs.

\section{Hasil Program}

Salah satu keberhasilan program YCPI ini adalah terciptanya sebuah rintisan usaha oleh peserta program, yaitu rintisan usaha aneka kue kering berbasis ubi kayu yang merupakan komoditas utama Desa Benteng. Aneka kue kering yang dihasilkan antara lain eggroll, nastar, kue kacang, dan kembang goyang. Selain itu, rintisan usaha ini akan dikembangkan juga untuk memproduksi tepung mocaf.

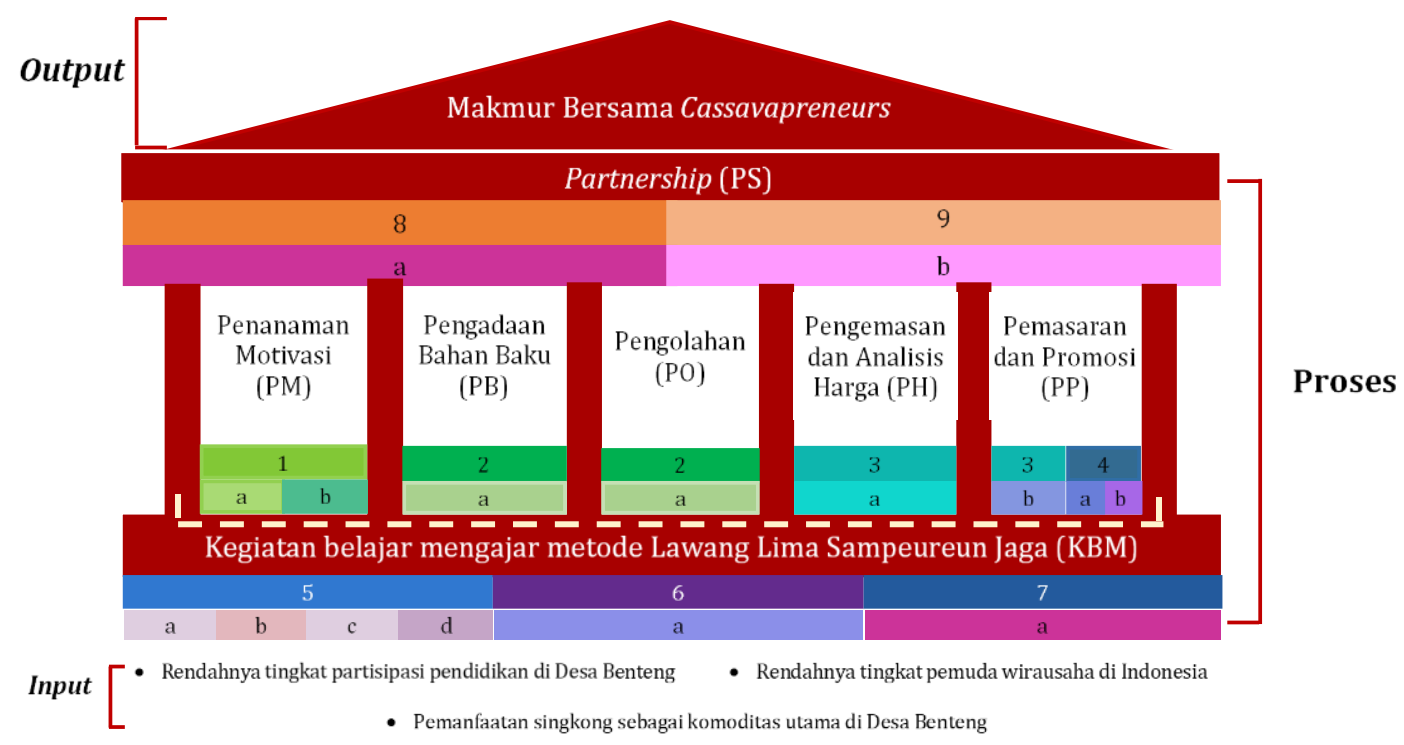

Gambar 1 Model Lawang Lima Sampeureun Jaga YCPI berbasis the house model (Horovitz \& Ohlsson 2007). 


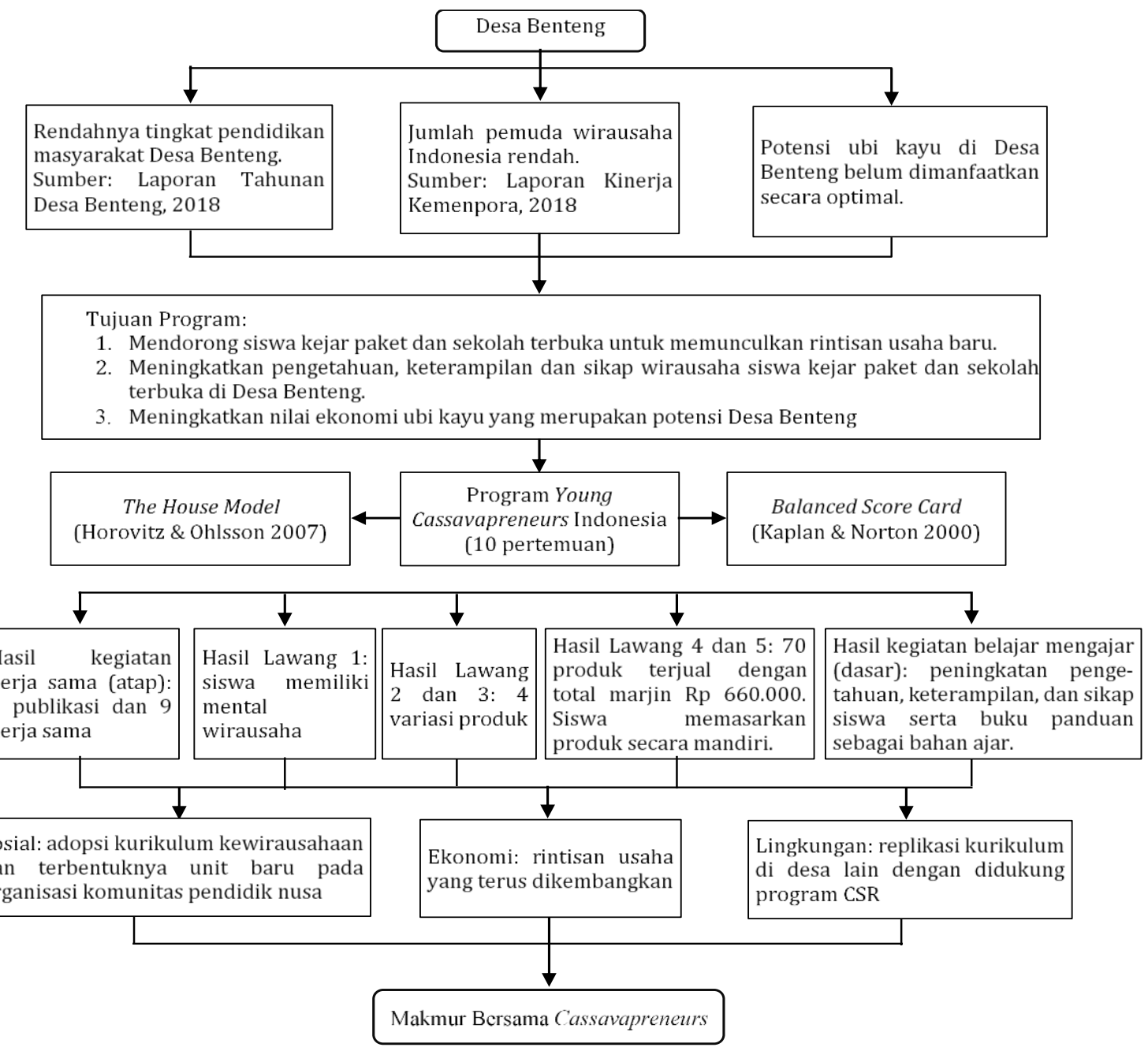

Gambar 2 Kerangka pemikiran Young Cassavapreneurs Indonesia.

\section{Hasil Evaluasi Lawang Pertama: Penanaman Motivasi}

Menurut Purwanto (2000) motivasi dapat memengaruhi prestasi belajar seseorang. Dalam pembelajaran kewirausahaan program YCPI motivasi dibentuk untuk menciptakan mental wirausaha pada peserta. Menurut Azzaini (2012) mental wirausaha dapat diukur dari kemampuan membangun tim, berkolaborasi, dan kemampuan beradaptasi.

Hasil pengukuran yang telah dilakukan kepemilikan mental wirausaha peserta telah mencapai target, yakni sebesar $84 \%$. Hal tersebut menunjukkan para siswa telah memiliki kemampuan bekerja sama dan membangun tim serta mampu beradaptasi terhadap perubahan. Mental wirausaha ini diharapkan dapat menjadi bekal peserta untuk bisa menjadi pengusaha dan manusia mandiri di masa mendatang. Persentase kehadiran menunjukkan konsistensi peserta mengikuti kegiatan dan indikator ini telah mencapai $92 \%$ atau melampaui target awal yang dapat dilihat pada Tabel 1.

\section{Hasil Evaluasi Lawang Kedua dan Ketiga: Pengadaan Bahan Baku dan Pengolahan Produk}

Pembelajaran pengadaan bahan baku dan pengolahan ubi kayu menjadi produk olahan ubi kayu telah dilakukan dengan 3 kali pertemuan. Produk olahan ubi kayu yang dihasilkan kemudian dipasarkan kepada konsumen secara online dan offline. Hasil evaluasi lawang kedua dan ketiga dapat dilihat pada Tabel 2. Berdasarkan Tabel 2 dapat diketahui bahwa target jumlah variasi produk olahan ubi kayu yang dihasilkan telah tercapai dari jumlah yang ditargetkan sebanyak dua varian menjadi lima varian. Varian produk yang dihasilkan di antaranya tepung eggroll, kue kacang, kembang goyang, dan nastar.

\section{Hasil Evaluasi Lawang Keempat dan Kelima: Pengemasan dan Pemasaran}

Para siswa telah belajar pengemasan produk yang baik untuk mempertahankan kualitas produk dan dapat menarik minat konsumen. Setelah pembelajaran pengemasan para siswa 
Tabel 1 Hasil evaluasi Lawang pertama

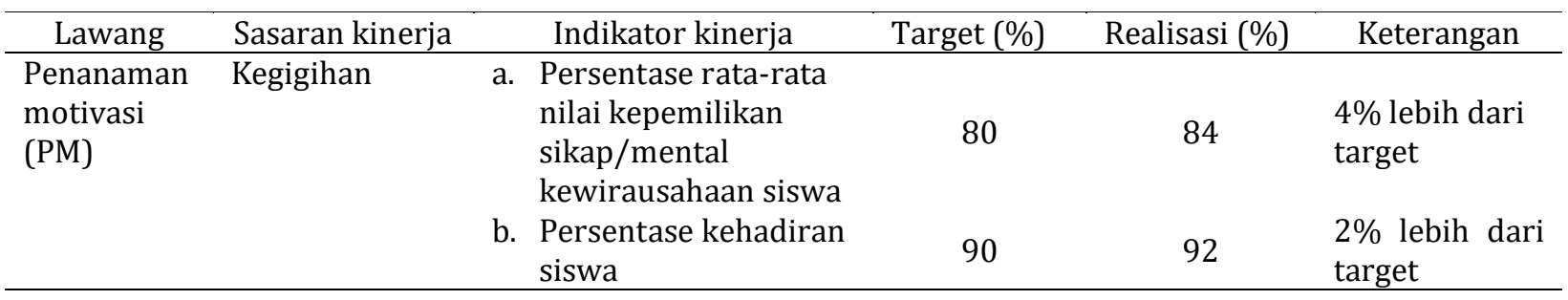

Tabel 2 Hasil evaluasi Lawang kedua dan ketiga

\begin{tabular}{cllccl}
\hline \multicolumn{1}{c}{ Lawang } & Sasaran kinerja & Indikator kinerja & Target & Realisasi & Keterangan \\
\hline $\begin{array}{l}\text { Pengadaan bahan baku dan } \\
\text { pengolahan (PB dan P0) }\end{array}$ & $\begin{array}{l}\text { Diversifikasi } \\
\text { produk }\end{array}$ & $\begin{array}{l}\text { Jumlah variasi produk } \\
\text { yang dihasilkan }\end{array}$ & 2 & 4 & $\begin{array}{l}50 \% \text { lebih } \\
\text { dari target }\end{array}$ \\
\hline
\end{tabular}

kemudian belajar materi dan praktik pemasaran. Praktik pemasaran dilakukan dengan berjualan online melalui marketplace dan berjualan langsung kepada konsumen di Lapangan Sempur, Kota Bogor. Hasil dari evaluasi lawang keempat dan kelima dapat dilihat pada Tabel 3.

Para peserta berhasil menjual 70 buah produk dengan 39 dijual melalui online dan 31 produk melalui offline. Penjualan online dilakukan melalui media sosial pribadi para siswa dan market place seperti shopee dan bukalapak. Para peserta memeroleh keuntungan sebesar Rp 660.000 dari hasil penjualan dan jumlah ini telah melebihi target awal sebesar 32\% yang dapat dilihat pada Tabel 3. Hal tersebut menunjukkan peserta telah memiliki keberanian dan kemauan untuk berjualan. Keberanian dan kemauan tersebut menjadi bekal peserta untuk menyongsong masa depan yang sejahtera.

Para peserta memanfaatkan media sosial pribadi untuk berjualan produk YCPI. Sebanyak 80\% peserta telah menjual produk YCPI melalui media sosialnya seperti facebook dan whatsapp. Hal tersebut menunjukkan para siswa memiliki kreatifitas dan kegigihan berjualan. Hasil menunjukkan bahwa $80 \%$ atau hampir seluruh peserta berhasil menjual minimal tiga satuan produk YCPI yang dapat dilihat pada Tabel 3.

\section{Hasil Evaluasi Kegiatan Belajar Mengajar}

Kegiatan belajar mengajar dilaksanakan dengan berpedoman pada Metode Lawang Lima Sampeureun Jaga yang terdiri atas penanaman motivasi, pengadaan bahan baku, pengolahan, pengemasan dan analisis harga jual, serta pemasaran. Evaluasi terkait kegiatan belajar mengajar dilakukan sebelum dan sesudah program dilaksanakan untuk memeroleh hasil pre-test dan post-test. Kegiatan evaluasi juga dilakukan pada setiap pertemuan, hasil evaluasi dapat dilihat pada Tabel 4.
Tabel 4 menunjukkan hasil penilaian meliputi persentase rata-rata pengetahuan yang diperoleh peserta mencapai $85 \%$, persentase rata-rata keterampilan peserta mencapai $83 \%$, dan persentase rata-rata sikap peserta mencapai $82 \%$. Ketiganya telah melampaui target awal yang ditentukan. Penilaian pre-test dan post-test juga dilakukan untuk mengukur perubahan sebelum dan setelah peserta mengikuti kegiatan YCPI. Hasil pre-test dan post-test menunjukkan persentase hasil capaian pembelajaran para peserta $\geq 3$ adalah $100 \%$ atau terjadi peningkatan pengetahuan, keterampilan, dan sikap para siswa secara keseluruhan setelah program berakhir. Terdapat dua jenis buku panduan, yakni buku panduan untuk siswa dan buku panduan untuk sekolah terbuka serta kejar paket B dan C di tempat lain dengan judul Makmur Bersama Cassavapreneurs' yang memiliki perolehan ISBN (978-602-440-785-8) untuk mendukung Kurikulum Pelatihan Kewirausahaan YCPI.

Level pembelajaran mengukur sejauh mana perubahan pengetahuan, keterampilan, dan sikap para peserta sebelum dan sesudah mengikuti program dengan melihat kesenjangan hasil penilaian. Kesenjangan hasil penilaian pre-test dan post-test digambarkan dengan Analisis Kesenjangan (Gap Analysis) seperti pada Gambar 3. Berdasarkan Gambar 3 para peserta program mengalami peningkatan nilai rata-rata pada seluruh lawang yang terdiri atas pengadaan bahan baku, pengolahan, pengemasan, dan analisis harga, serta pemasaran yang terbagi dalam evaluasi melalui pre-test dan post-test dengan masing-masing peningkatan sebesar 37\% pada aspek pengetahuan, $46 \%$ pada aspek keterampilan, dan $41 \%$ pada aspek sikap. Hasil nilai ratarata pre-test siswa (pengetahuan, keterampilan, dan sikap) dari 13 indikator hanya 1 indikator yang nilainya lebih 3. Pada post-test YCPI menargetkan perkembangan pembelajaran tersebut 
Tabel 3 Hasil evaluasi Lawang keempat dan kelima

\begin{tabular}{|c|c|c|c|c|c|}
\hline Lawang & Sasaran kinerja & Indikator kinerja & Target & Realisasi & Pencapaian \\
\hline \multirow{4}{*}{$\begin{array}{l}\text { Pengemasan } \\
\text { dan analisis } \\
\text { harga serta } \\
\text { pemasaran } \\
\text { dan promosi } \\
\text { (PH dan PP) }\end{array}$} & \multirow[t]{2}{*}{ Penjualan } & $\begin{array}{l}\text { a. Jumlah produk } \\
\text { berhasil terjual } \\
\text { seluruh } \text { event }\end{array}$ & 50 & 70 & $\begin{array}{l}28 \% \text { lebih } \\
\text { dari target }\end{array}$ \\
\hline & & $\begin{array}{l}\text { b. Jumlah total marjin yang } \\
\text { diperoleh }\end{array}$ & Rp 500.000 & Rp 660.000 & $\begin{array}{l}24 \% \text { lebih } \\
\text { dari target }\end{array}$ \\
\hline & \multirow[t]{2}{*}{ Pemasaran } & $\begin{array}{l}\text { a. Persentase kepemilikan } \\
\text { media wirausaha mandiri } \\
\text { lainnya diluar usaha YCPI } \\
\text { (contoh: berjualan di } \\
\begin{array}{l}\text { instagram, } \\
\text { pribadi) }\end{array}\end{array}$ & $70 \%$ & $80 \%$ & $\begin{array}{l}10 \% \text { lebih } \\
\text { daari target }\end{array}$ \\
\hline & & $\begin{array}{l}\text { b. Persentase siswa yang } \\
\text { dapat menjual minimal } 3 \\
\text { satuan produk }\end{array}$ & $70 \%$ & $80 \%$ & $\begin{array}{l}10 \% \text { lebih } \\
\text { dari target }\end{array}$ \\
\hline
\end{tabular}

Tabel 4 Hasil evaluasi kegiatan belajar mengajar

\begin{tabular}{|c|c|c|c|c|c|}
\hline Dasar & Sasaran kinerja & Indikator kinerja & Target $(\%)$ & Realisasi (\%) & Keterangan \\
\hline \multirow{6}{*}{$\begin{array}{l}\text { Kegiatan } \\
\text { belajar } \\
\text { mengajar } \\
(\mathrm{KBM})\end{array}$} & $\begin{array}{l}\text { Keinginan } \\
\text { belajar }\end{array}$ & $\begin{array}{l}\text { a. Persentase nilai rata-rata } \\
\text { pengetahuan para siswa }\end{array}$ & 80 & 85 & $\begin{array}{l}5 \% \text { lebih } \\
\text { dari target }\end{array}$ \\
\hline & & $\begin{array}{l}\text { b. Persentase nilai rata-rata } \\
\text { keterampilan para siswa }\end{array}$ & 80 & 83 & $\begin{array}{l}3 \% \text { lebih } \\
\text { dari target }\end{array}$ \\
\hline & & $\begin{array}{l}\text { c. Persentase nilai rata-rata } \\
\text { perilaku para siswa }\end{array}$ & 80 & 82 & $\begin{array}{l}2 \% \text { lebih } \\
\text { dari target }\end{array}$ \\
\hline & & $\begin{array}{l}\text { d. Persentase hasil capaian } \\
\text { pembelajaran siswa melalui } \\
\text { post-test } \geq 3\end{array}$ & 80 & 100 & $\begin{array}{l}20 \% \text { lebih } \\
\text { dari target }\end{array}$ \\
\hline & $\begin{array}{l}\text { Buku panduan } \\
\text { siswa }\end{array}$ & $\begin{array}{l}\text { Persentase penyelesaian buku } \\
\text { panduan kewirausahaan bagi } \\
\text { siswa }\end{array}$ & 100 & 100 & $\begin{array}{l}\text { Sama } \\
\text { dengan } \\
\text { target }\end{array}$ \\
\hline & $\begin{array}{l}\text { Buku panduan } \\
\text { untuk } \\
\text { masyarakat }\end{array}$ & $\begin{array}{l}\text { Persentase penyelesaian buku } \\
\text { panduan kewirausahaan bagi } \\
\text { pemangku } \\
\text { masyarakat }\end{array}$ & 100 & 100 & $\begin{array}{l}\text { Sama } \\
\text { dengan } \\
\text { target }\end{array}$ \\
\hline
\end{tabular}

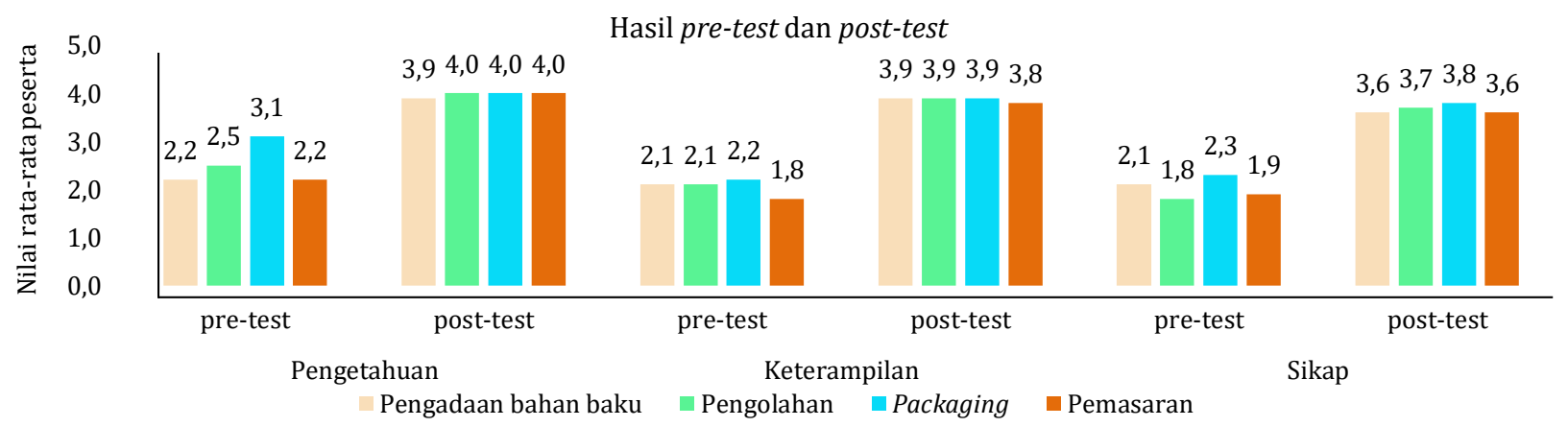

Gambar 3 Analisis kesenjangan hasil pre-test dan post-test.

minimum pada angka 3 dan setelah 10 pertemuan semua indikator telah melampaui angka 3.

\section{Hasil Evaluasi Publikasi dan Kerja Sama}

Kegiatan YCPI perlu dipublikasikan untuk menginspirasi masyarakat luar tergerak melaksanakan program yang sejenis. YCPI telah melakukan berbagai publikasi melalui media cetak, elektronik, dan jurnal yang merupakan partner dalam memperluas manfaat dan dampak dari kegiatan YCPI. Media yang telah bekerja sama dan meliput program YCPI terangkum pada Tabel 5. Berdasarkan Tabel 5 dapat diketahui indikator publikasi yang telah dilakukan dan kerja sama terjalin dengan pihak eksternal telah melampaui target yang telah ditetapkan. Adapun 
Tabel 5 Hasil evaluasi publikasi dan partnership

\begin{tabular}{llllcccc}
\hline \multicolumn{1}{c}{ Atap } & Sasaran kinerja & \multicolumn{2}{c}{ Indikator kinerja } & Target & Realisasi & Keterangan \\
\hline $\begin{array}{l}\text { Kerja sama } \\
\text { (PS) }\end{array}$ & Publikasi & $\begin{array}{l}\text { Jumlah publikasi yang } \\
\text { dilakukan }\end{array}$ & telah & 3 & 6 & $\begin{array}{l}50 \% \text { melebihi } \\
\text { target }\end{array}$ \\
\cline { 2 - 7 } & Kerja sama & $\begin{array}{l}\text { Jumlah kerja sama yang terjalin } \\
\text { dengan pihak eksternal }\end{array}$ & 5 & 10 & $\begin{array}{l}50 \% \text { melebihi } \\
\text { target }\end{array}$ \\
\hline
\end{tabular}

media yang telah meliput kegiatan ini di antaranya Koran Harian Pakuan Raya, Good News From Indonesia, Kumparan, IPB News, Tribun News, dan radio RRI Pro 2 Bogor. Untuk publikasi ilmiah, Tim YCPI telah mengajukan ke Agrokreatif Jurnal Ilmiah Pengabdian kepada Masyarakat. Harapan dengan adanya berbagai publikasi tersebut mampu membuat masyarakat terinspirasi dan tergerak hatinya untuk melakukan program sejenis yang bermanfaat bagi sesama.

Berdasarkan Tabel 5 dapat diketahui indikator publikasi yang telah dilakukan dan kerja sama terjalin dengan pihak eksternal telah melampaui target yang telah ditetapkan. Adapun media yang telah meliput kegiatan ini di antaranya Koran Harian Pakuan Raya, Good News From Indonesia, Kumparan, IPB News, Tribun News, dan radio RRI Pro 2 Bogor. Untuk publikasi ilmiah, tim YCPI telah mengajukan ke Agrokreatif Jurnal Ilmiah Pengabdian kepada Masyarakat. Adanya publikasi tersebut diperuntukkan agar masyarakat terinspirasi dan tergerak hatinya untuk melakukan program sejenis yang bermanfaat bagi sesama.

Realisasi program kerja sama yang telah terjalin selama program berdasarkan Pentahelix (Amrial et al. 2017) adalah kerja sama dengan sektor akademik, yaitu pengelola sekolah terbuka dan kejar paket Desa Benteng melalui sinergitas struktur organisasi YCPI dengan kepengurusan sekolah terbuka dan kejar paket Desa Benteng. Kerja sama dengan sektor bisnis, yakni dengan PT Paragon Technology and Innovation melalui CSR untuk replikasi kurikulum program pelatihan kewirausahaan di Desa Cikarawang, LSP Menbiska melalui reviewer Buku Panduan Makmur bersama YCPI, IPB Press melalui kerja sama internal penerbitan buku panduan YCPI, dan Botani mart melalui kerja sama pemasaran produk yang dihasilkan. Kerja sama dengan sektor pemerintah melalui BUMDes Sakinah Desa Benteng dengan bentuk kerja sama pemasaran produk yang telah dihasilkan dan pengembangan usaha. Kerja sama dengan sektor non pemerintah, yakni Yayasan Basmi
Kemiskinan (YBK) melalui pemberian apresiasi dan inisiasi kerja sama penulisan kasus pemberantasan kemiskinan Indonesia dan Malaysia. Kerja sama dengan masyarakat melalui Komunitas Pendidik Nusa dalam pendampingan kelanjutan program dan KWT Barokah dalam memfasilitasi peralatan pengolahan.

Berdasarkan hasil evaluasi, dapat diketahui seluruh indikator telah melampaui target yang ditetapkan sehingga capaian program secara keseluruhan berdasarkan Balanced Score Card (BSC) adalah 100\%. Bukan hanya itu, hasil analisis kesenjangan juga menunjukkan adanya peningkatan pengetahuan, keterampilan, dan sikap.

\section{Potensi Keberlanjutan Program}

Menurut segitiga konsep pembangunan berkelanjutan (Environmentally Sustainable Development Triangle-World Bank, Serageldin \& Seeter 1994 dalam Dahuri 1998) terdapat tiga dimensi utama yaitu dimensi sosial, ekonomi, dan lingkungan.

\section{- Keberlanjutan dimensi sosial program YCPI}

Program YCPI telah diadopsi sebagai kurikulum pelatihan kewirausahaan oleh sekolah terbuka dan kejar paket Desa Benteng yang akan didampingi oleh Komunitas Pendidik Nusa dengan membentuk unit baru pada struktur kelembagaan wirausaha YCPI yang dapat dilihat pada Gambar 4. Selain itu, terbentuk agen-agen YCPI yang dapat menggerakan pemuda desa dan membantu memajukan desa.

\section{- Keberlanjutan dimensi ekonomi}

Rintisan usaha yang sudah dikembangkan oleh peserta program dengan produk aneka kue kering dan tepung mocaf akan menjamin keberlanjutan pada dimensi ekonomi. Rintisan usaha ini akan terus dikembangkan menjadi sebuah usaha berbadan hukum dengan melengkapi segala persyaratannya termasuk PIRT. Pengembangan rintisan usaha berbadan hukum ini dapat didukung oleh Badan Usaha Milik Desa Sakinah Desa Benteng. 


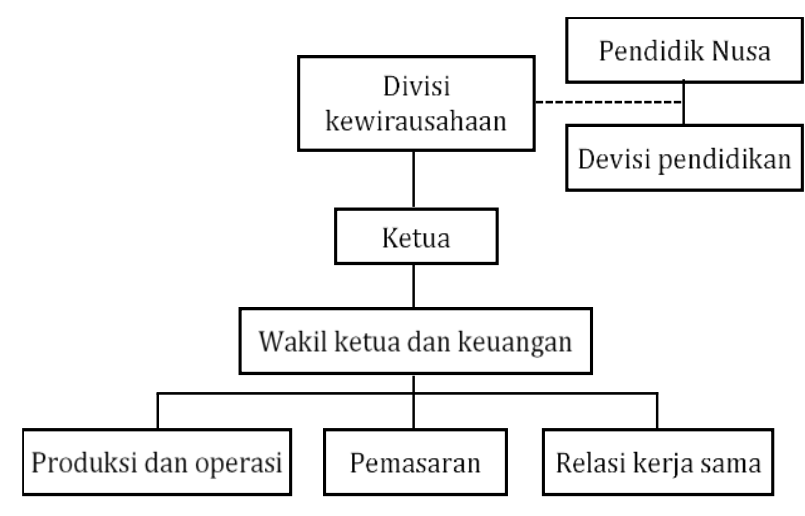

Gambar 4 Struktur kelembagaan wirausaha YCPI.

\section{- Keberlanjutan dimensi perluasan dampak lingkungan}

Tim YCPI telah melaksanakan perekrutan relawan pengajar untuk replikasi Kurikulum Pelatihan Kewirausahaan YCPI di desa lain yang didukung oleh buku panduan 'Makmur Bersama Cassavapreneurs'. Hal tersebut didukung oleh kerja sama YCPI bersama CSR PT Paragon Technology and Innovation. Inisiasi kerja sama YCPI IPB dengan Yayasan Basmi Kemiskinan (YBK) Malaysia terkait penyusunan buku dengan topik Model Pemberantasan Kemiskinan melalui Wirausaha Muda (Studi Kasus IndonesiaMalaysia) yang akan diterbitkan dalam Bahasa Indonesia dan Bahasa Melayu. Pengembangan Program YCPI dapat dilakukan dengan memanfaatkan potensi komoditas lokal. Sebagai mitra, kegiatan wirausaha ini tidak harus dengan sekolah terbuka tetapi juga dapat bekerja sama dengan karang taruna.

\section{Strategi dan Desain Pengembangan Program}

Berdasarkan hasil evaluasi program, dapat dirumuskan strategi dan desain pengembangan program dengan menggunakan SWOT analysis dan Force Field Analysis (FFA). Menurut David (2010) SWOT merupakan instumen penting yang digunakan oleh para manajer untuk menyusun strategi S-O (kekuatan-kelemahan), S-T (kekuatan-ancaman), W-O (kelemahan-peluang), dan W-T (kelemahan ancaman). Hasil analisis SWOT Desa Benteng dapat dilihat pada Tabel 6.

Berdasarkan hasil analisis SWOT pada Tabel 6 dapat diketahui terdapat empat strategi untuk pengembangan Desa Benteng. Strategi utama yang dapat diterapkan adalah strategi S-O (kekuatan-peluang), yakni dengan implementasi program YCPI sebagai program kewirausahaan kreatif di Desa Benteng. Penyelenggaraan program YCPI dapat digunakan untuk memaksimalkan peluang yang ada, kekuatan Desa Benteng seperti produksi singkong yang melimpah, motivasi remaja desa yang tinggi untuk berwirausaha, dan lengkapnya peralatan pengolahan yang dimiliki KWT Desa Benteng. Produk yang dihasilkan YCPI diharapkan dapat menjadi produk khas Desa Benteng, dan pemasarannya meluas hingga seluruh nusantara.

Force Field Analysis (FFA) adalah terdiri dari faktor pendukung atau faktor yang diharapkan ada untuk melancarkan implementasi program dan faktor penghambat atau faktor yang diharapkan tidak muncul karena dapat menghambat pelaksanaan program. Desain FFA untuk keberlanjutan program dapat dilihat pada Gambar 5.

Menurut Shenhar \& Dvir (2007) terdapat lima dimensi kesuksesan suatu projek. Lima dimensi tersebut adalah projek efisiensi, kepuasan tim, kesuksesan bisnis, persiapan untuk masa depan, dan dampak pada pelanggan. Dari lima dimensi kesuksesan tersebut, hanya dimensi efisiensi kegiatan, kepuasan tim, kesuksesan bisnis dan persiapan untuk masa depan yang merupakan faktor pendukung kesuksesan program YCPI. Efisiensi kegiatan dipengaruhi oleh waktu dan anggaran. Program YCPI dapat dikatakan efisien karena berhasil menyelesaikan kegiatan sesuai dengan timeline yang direncanakan dan anggaran yang dikelola telah memenuhi sasaran anggaran. Dimensi kepuasan tim diukur dengan pengembangan keterampilan tim, dan pertumbuhan anggota tim. Dalam hal ini keberhasilan program YCPI dalam meningkatkan pengetahuan, keterampilan, dan sikap para peserta menjadi salah satu faktor pendukung keberhasilan program. Kesuksesan bisnis diukur dengan peningkatan pangsa pasar produk olahan singkong. Program YCPI berhasil meningkatkan pangsa pasar produk olahan singkong. Sebelum adanya program YCPI, produk olahan singkong hanya dijual ke orang-orang di sekitar desa, namun setelah adanya program ini olahan singkong dapat dijual ke konsumen lebih luas melalui media sosial, toko online, dan kerja sama dengan retail.

Dimensi persiapan untuk masa depan diukur dengan bagaimana menciptakan produk baru, dan pasar baru, untuk keberlanjutan program YCPI. Adanya pasar yang dapat menerima produk-produk olahan YCPI merupakan salah satu faktor penting yang mendukung keberlanjutan program ini. Oleh karena itu, program YCPI telah memperluas pangsa pasar melalui penjualan online dan membuat produk olahan singkong menjadi berbagai varian untuk per- 
Tabel 6 Analisis SWOT

\begin{tabular}{|c|c|c|}
\hline Eksternal & $\begin{array}{l}\text { Opportunities }(0) \\
\text { 1.Luasnya pasar produk olahan } \\
\text { singkong } \\
\text { 2.Produk olahan singkong dapat } \\
\text { menjadi produk khas Desa } \\
\text { Benteng. }\end{array}$ & $\begin{array}{l}\text { Threats }(\mathrm{T}) \\
\text { 1.Banyak kompetitor yang } \\
\text { menjual produk olahan } \\
\text { singkong } \\
\text { 2.Pengurusan sertifikasi } \\
\text { halal. }\end{array}$ \\
\hline $\begin{array}{l}\text { Strenghts }(\mathrm{S}) \\
\text { 1.Produksi singkong yang melimpah } \\
\text { 2. Tingginya motivasi remaja desa untuk } \\
\text { berwirausaha } \\
\text { 3. Kelompok Wanita Tani (KWT) yang } \\
\text { memiliki peralatan pengolahan } \\
\text { singkong. }\end{array}$ & $\begin{array}{l}\text { S-O } \\
\text { Program Young Cassava Preneurs } \\
\text { Indonesia sebagai program } \\
\text { kewirausahaan kreatif di Desa } \\
\text { Benteng. }\end{array}$ & $\begin{array}{l}\text { S-T } \\
\text { Membuat produk olahan } \\
\text { singkong dengan kualitas } \\
\text { tinggi dan bersertifikat halal } \\
\text { serta melakukan pemasaran } \\
\text { secara optimal. }\end{array}$ \\
\hline $\begin{array}{l}\text { Weaknesses }(\mathrm{W}) \\
\text { 1.Pendidikan masyarakat Desa Benteng } \\
\text { belum merata. } \\
\text { 2. Masih adanya pengangguran di Desa } \\
\text { Benteng. } \\
\text { 3.Pemanfaatan singkong menjadi } \\
\text { produk lain belum optimal. }\end{array}$ & $\begin{array}{l}\text { W-O } \\
\text { Mengoptimalkan pengolahan dan } \\
\text { pemasaran produk singkong } \\
\text { sehingga dapat menjadi produk } \\
\text { khas desa dan dapat } \\
\text { meningkatkan perekonomiman } \\
\text { desa. }\end{array}$ & $\begin{array}{lr}\text { W-T } & \\
\text { Meningkatkan } & \text { kesadaran } \\
\text { masyarakat } & \text { khususnya } \\
\text { generasi muda Desa Benteng } \\
\text { akan } & \text { pentingnya } \\
\text { berwirausahar } & \end{array}$ \\
\hline
\end{tabular}

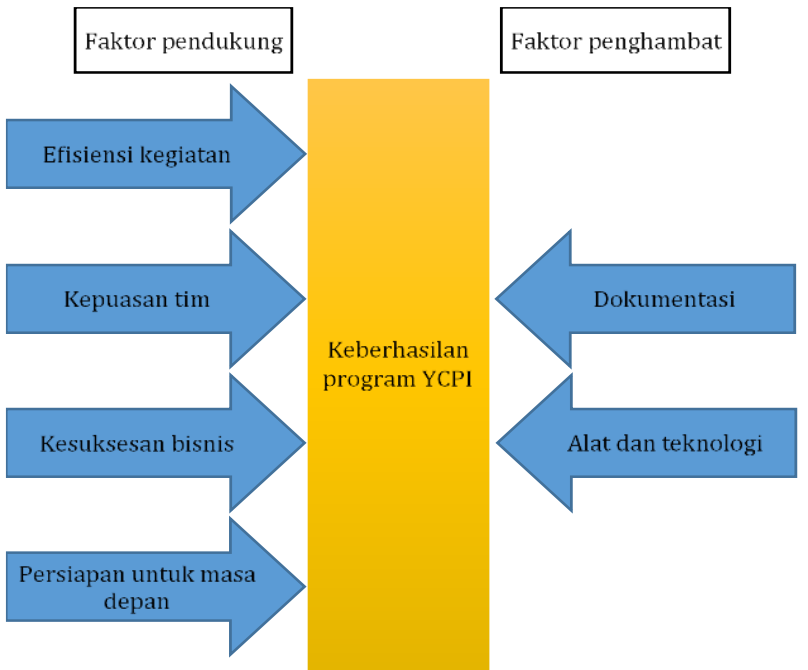

Gambar 5 Desain keberlanjutan YCPI dengan force field analysis.

siapan di masa mendatang. Di sisi lain terdapat faktor penghambat yang dapat menghambat program YCPI. Menurut Nasir et al. (2008) faktor penghambat keberhasilan suatu projek di antaranya anggaran dan estimasi biaya, dokumentasi, kualitas, alat dan teknologi. Di antara keempat faktor penghambat keberhasilan program tersebut hanya faktor dokumentasi serta alat dan teknologi yang menjadi faktor penghambat keberhasilan program YCPI. Dimensi dokumentasi diukur dengan pengumpulan data. Dalam program YCPI salah satu hal yang menghambat pelaksanaan program adalah keterbatasan real time data tentang tingkat produksi dan konsumsi singkong di Desa Benteng, serta jumlah singkong yang tidak diolah atau dimanfaatkan sehingga tidak dapat di- ketahui presentase penurunan singkong yang tidak dimanfaatkan setelah adanya program YCPI. Selain itu, faktor penghambat lainnya adalah alat dan teknologi. Saat ini, teknologi yang digunakan untuk mengolah singkong menjadi tepung mocaf masih menggunakan blender dan jumlahnya terbatas sehingga dibutuhkan waktu yang cukup lama mengolahnya. Bukan hanya itu, alat pengolahan tepung mocaf menjadi varian eggroll juga masih menggunakan alat sederhana.

\section{SIMPULAN}

Program Young Cassavapreneurs Indonesia (YCPI) mendorong peserta untuk memunculkan rintisan usaha berbasis potensi lokal. Program ini telah meningkatkan pengetahuan, keterampilan, dan sikap peserta terkait kewirausahaan yang diukur menggunakan pre-test dan post-test sehingga peserta memiliki rintisan usaha aneka kue kering. Diversifikasi produk olahan berbasis ubi kayu menghasilkan produk yang memiliki nilai jual lebih tinggi. Total marjin yang diperoleh yaitu sebesar Rp 660.000 dalam kurun waktu 1,5 bulan, hal tersebut membuktikan bahwa terjadi peningkatan nilai ekonomi ubi kayu. Program YCPI dievaluasi menggunakan Balance Score Card, di mana hasil menunjukkan bahwa seluruh indikator utama kegiatan YCPI dicapai dengan sangat baik $(\geq 100 \%)$. Proses Pembelajaran YCPI telah diadopsi sebagai kurikulum pelatihan kewirausahaan oleh Sekolah Terbuka dan Kejar Paket Desa Benteng dengan membentuk struktur 
kelembagaan wirausaha YCPI yang bernaung dalam unit baru, divisi kewirausahaan Komunitas Pendidik Nusa. Kelembagaan wirausaha baru ini dapat memaksimalkan peluang dan potensi wirausaha yang telah dimiliki Desa Benteng seperti produksi singkong yang melimpah, motivasi remaja desa yang tinggi untuk berwirausaha, dan lengkapnya peralatan pengolahan.

\section{UCAPAN TERIMA KASIH}

Rasa terima kasih kami sampaikan kepada Kementerian Riset, Teknologi, dan Pendidikan Tinggi yang telah membiayai perintisan program Young Cassavapreneurs Indonesia melalui Program Kreativitas Mahasiswa bidang Pengabdian Masyarakat (PKM-M) pada tahun 2019.

\section{DAFTAR PUSTAKA}

Amrial, Muhammad E, Adrian AM. 2017. Penta Helix Model: A Sustainable Development Solution Through The Industrial Sector. Social and Human Sciences. In: Conference: 14th Hokkaido Indonesian Student Association Scientific Meeting, At Sapporo, Japan (JP).

Azzaini J. 2012. Mental Wirausaha. [Internet]. [diakses 26 Juni 2019]. Tersedia pada: http://www.jamilazzaini.com/mentalwirausaha/.
[BPS] Badan Pusat Statistik. 2018. Produksi Ubi kayu Kabupaten Bogor. [Internet]. [Diakses 11 Juli 2019]. Tersedia pada http://bogorkab.bps.go.id.

Dahuri R. 1998. Pembangunan Pertanian Berkelanjutan: Dalam Perspektif Ekonomi, Sosial dan Ekologi. Agrimedia. 4(1): 5-11.

David F. 2010. Manajemen Strategis Konsep. Jakarta (ID): Salemba Empat.

Horovitz J, Ohlsson-Corboz A. 2007. A Dream with Deadline: Turning Strategy Into Action. Amazon (US): Trans-Atlantic Publications, Inc.

Kaplan RS, Norton DP. 2000. Balanced Scorecard: Menerapkan Strategi Menjadi Aksi. Jakarta (ID): Erlangga.

Kementerian Pemuda Olahraga. 2018. Laporan Kinerja Kemenpora. Diakses tanggal 11 Oktober 2018. Tersedia pada https://www.kemenpora.go.id.

Nasir M, Ahmad R, Hassan NH. 2008. Resistance Factors in the Implementation Software Process Improvement Project. Journal of Computer Science. 4(3): 211-219. https://doi.org/10.3844/jcssp.2008.211.219

Purwanto M. 2000. Psikologi Pendidikan. Bandung (ID): Remaja Rosdakarya.

Shenhar A, Dvir D. 2007. Reinventing project management: The diamond approach to successful growth and innovation. Boston (US): Harvard Business Press. 